\title{
HUBUNGAN PENGGUNAAN TUSUK GIGI TERHADAP TERJADINYA SAKU GUSI PADA MASYARAKAT DUSUN II DESA MARINDAL II KECAMATAN PATUMBAK KABUPATEN DELI SERDANG TAHUN 2016
}

\author{
Kartika Emailijati $^{\bowtie 1}$, Adriana Hamsar ${ }^{2}$, Etty M. Marthias ${ }^{3}$, Nurul Aini ${ }^{4}$
}

\begin{abstract}
ABSTRAK
Tusuk gigi adalah sebatang kayu atau plastik yang digunakan untuk menyingkirkan sisa-sisa makanan dari gigi. Penggunaan tusuk gigi yang tidak tepat dapat melukai jaringan lunak sekitar gigi dan menyebabkan keradangan pada jaringan lunak mukosa rongga mulut. Survei awal yang dilakukan di Dusun II Desa Marindal II Kecamatan Patumbak ditemukan bahwa 25\% masyarakat yang menggunakan tusuk gigi dalam kehidupan sehari-hari, mengeluhkan adanya gusi berdarah dan gigi menjadi renggang.

Jenis penelitian yang dilakukan adalah penelitian analitik dengan metode case control dengan jumlah populasi 520 orang. Sampel berjumlah 52 orang dan dibagi menjadi 2 kelompok, 26 orang menggunakan tusuk gigi dan 26 orang tidak menggunakan tusuk gigi.

Hasil yang didapat dalam penelitian ini menunjukkan bahwa penggunaan tusuk gigi memungkinkan terjadinya saku gusi dibandingkan tidak menggunakan tusuk gigi. Hal ini dapat dilihat dari perbedaan skor CPITN, skor tertinggi pada penggunaan tusuk gigi adalah skor 3 dengan persentasi sebesar 53,8\% dan yang tidak menggunakan tusuk gigi skor tertinggi didapat pada skor 2 sebesar 73,1\%. Analisis statistik dengan uji chi-square mendapatkan nilai probabilitas 0,0001 ( $p<0,05)$. Kesimpulan dari penelitian ini adalah $\mathrm{H}_{0}$ ditolak yang berarti ada hubungan penggunaan tusuk gigi terhadap terjadinya saku gusi.
\end{abstract}

Kata kunci : Tusuk Gigi, Saku Gusi

\begin{abstract}
Toothpick is a piece of wooden or plastic stick used to remove food accumulated from teeth. The improper use of toothpick can damage the soft tissues around the tooth and cause inflammation on the mucosa tissue of the oral cavity. The preliminary survey conducted in Dusun II, Mariendal II Village, Patumbak Subdistrict found that $25 \%$ of the residents who used toothpick complaint about bleeding gum and gap-tooth.

This is an analytical research with case control method with population of 520 people. The samples were 52 respondents who were divided into two groups; the first 26 respondents used toothpick and the other 26 respondents did not use toothpick.

The results showed that the uses of toothpick may cause periodontal pocket compared to the group who did not use them. It could be seen from the score difference for CPITN (Community Periodontal Index of Treatment Needs), the highest score indicated by the group that used toothpick was 3 which was represented by $53.8 \%$ and the highest score obtained by the group that did not use toothpick was 2 which was represented by $73.1 \%$. The statistical analysis with chi-square test gained probability value 0.0001 ( $p<0.05)$. In conclusion, $H_{0}$ was rejected which meant that there was a correlation between the uses of toothpick and the incidence of periodontal pocket.
\end{abstract}

Key words : Toothpick, Periodontal Pocket

1) Instruktur Jurusan Keperawatan Gigi Poltekkes Kemenkes Medan

${ }^{2,3}$ ) Dosen Jurusan Keperawatan Gigi Poltekkes Kemenkes Medan

${ }^{4}$ ) Mahasiswa Jurusan Keperawatan Gigi Poltekkes Kemenkes Medan

: kartikaemailijati@gmail.com 


\section{PENDAHULUAN}

Hampir semua restoran ataupun rumah tangga menyediakan tusuk gigi, mulai dari yang memperhatikan kebersihan (terbungkus) sampai sekadar dari potongan kayu/lidi yang diletakkan di atas meja makan (Grace, 2011).

Menurut Citra Kusumasari, tusuk gigi merupakan alat bantu untuk membersihkan gigi sebelum ditemukannya sikat gigi

Penggunaan tusuk gigi tidak tepat bagi gusi dan gigi. Bentuk yang tidak sesuai dengan anatomis gusi dan gigi akan menyebabkan luka dan pendarahan bagi gusi dan tusuk gigi tidak steril dapat menyebabkan Infeksi pada rongga mulut. (Doktersehat, 2015).

Kebiasaan menggunakan tusuk gigi dengan cara mencolok/menusuk dan mengungkit dapat mengganggu jaringan pendukung gigi dan dapat mengakibatkan terjadinya peradangan pada gusi (Erwana, 2013).

Tujuan Penelitian untuk mengetahui hubungan penggunaan tusuk gigi terhadap terjadinya saku gusi pada masyarakat Dusun II Desa Marindal II Kecamatan Patumbak

\section{METODE PENELITIAN}

Jenis penelitian yang dilakukan adalah penelitian analitik dengan metode case control pada masyarakat Dusun II Desa Marindal II Kecamatan Patumbak, dimana penelitian ini bertujuan untuk mengetahui hubungan penggunaan tusuk gigi terhadap terjadinya saku gusi pada pada masyarakat
Dusun II Desa Marindal II Kecamatan Patumbak.

Populasi yang diambil dalam penelitian ini adalah masyarakat Dusun II Desa Marindal II Kecamatan Patumbak yang berjumlah 520 orang..Pengambilan sampel secara purposive sampling sebanyak 52 orang dengan kriteria sebagai berikut :

1. Dewasa usia minimal 20 tahun.

2. Bersedia menjadi sampel dalam penelitian ini.

Data penelitian ini disajikan :

\section{Analisa Univariat}

Analisa univariat pada penelitian ini bertujuan untuk melihat gambaran distribusi frekuensi dan proporsi variabel yang diteliti baik variabel dipendent maupun independent.

\section{Analisa Bivariat}

Analisa bivariat pada penelitian ini bertujuan untuk mengetahui hubungan dua variabel yaitu antara variabel dependent dengan variabel independent. Pada penelitian ini analisa bivariat yang digunakan adalah $u j i$ Chi-Square. Variabel independent yang telah di kategorikan diuji apakah ada hubungan penggunaan tusuk gigi terhadap terjadinya saku gusi. Jika nilai $p<0,05 \mathrm{H}_{0}$ ditolak dan $\mathrm{H}_{\mathrm{a}}$ diterima.

\section{HASIL DAN PEMBAHASAN}

\section{Analisa Univariat}

Analisa univariat pada penelitian inii bertujuan untuk melihat gambaran distribusi frekuensi dan proporsi variabel yang diteliti baik variabel dipendent maupun independen.

Tabel 1. Distribusi, Persentase Skor CPITN Pada Masyarakat Dusun II Desa Marindal II Kecamatan Patumbak

\begin{tabular}{|c|c|c|c|c|c|c|c|c|c|c|c|c|}
\hline \multirow{2}{*}{\multicolumn{2}{|c|}{$\Sigma$}} & \multicolumn{10}{|c|}{ Skor CPITN } & \multirow{3}{*}{$\begin{array}{l}\text { Kelompok } \\
\text { Pengamatan }\end{array}$} \\
\hline & & \multicolumn{2}{|c|}{4} & \multicolumn{2}{|c|}{3} & \multicolumn{2}{|c|}{2} & \multicolumn{2}{|c|}{1} & \multicolumn{2}{|c|}{0} & \\
\hline$\%$ & $\mathrm{n}$ & $\%$ & $\mathrm{n}$ & $\%$ & $\mathrm{n}$ & $\%$ & $\mathrm{n}$ & $\%$ & $\mathrm{n}$ & $\%$ & $\mathrm{n}$ & \\
\hline 100 & 26 & 34,7 & 9 & 53,8 & 14 & 11,5 & 3 & 0 & 0 & 0 & 0 & $\begin{array}{c}\text { Menggunakan } \\
\text { Tusuk Gigi }\end{array}$ \\
\hline 100 & 26 & 0 & 0 & 15,4 & 4 & 73,1 & 19 & 11,5 & 3 & 0 & 0 & $\begin{array}{c}\text { Tidak } \\
\text { Menggunakan } \\
\text { Tusuk Gigi }\end{array}$ \\
\hline
\end{tabular}


Berdasarkan tabel 1. dapat diketahui bahwa persentase skor CPITN pada 26 responden yang menggunakan tusuk gigi dengan skor tertinggi adalah skor 3 sebanyak 14 orang $(53,8 \%)$. Skor 3 menunjukkan adanya saku gusi dangkal (3,5-5,5 mm). Sedangkan skor tertinggi CPITN pada 26 responden yang tidak menggunakan tusuk gigi adalah skor 2 sebanyak 19 orang $(73,1 \%)$. Skor 2 menunjukkan adanya kalkulus subgingiva.

Tabel 2. Distribusi Persentase Skor CPITN

Berdasarkan Jenis Kelamin Pada Masyarakat Dusun II Desa Marindal II Kecamatan Patumbak Jenis Kelamin

\begin{tabular}{ccc}
\hline $\begin{array}{c}\text { Perempuan } \\
(\%)\end{array}$ & Laki-laki $(\%)$ & Skor \\
\hline 0 & 0 & 0 \\
3,8 & 1,9 & 1 \\
21,2 & 21,2 & 2 \\
19,2 & 15,4 & 3 \\
1,9 & 15,4 & 4 \\
46,1 & 53,9 & Jumlah \\
\hline
\end{tabular}

Berdasarkan tabel di atas, dapat dilihat bahwa ada perbedaan skor CPITN. Pada skor 0 terlihat bahwa laki-laki dan perempuan tidak ada yang memiliki gigi sehat. Perempuan memiliki persentase lebih kecil $(3,8 \%)$ pada skor 1 dibandingkan dengan laki-laki (1,9\%). Sementara untuk skor 2, yaitu adanya karang gigi subgingival, laki-laki dan perempuan memiliki persentase yang sama yaitu 21,2\%. Pada skor 3 (saku gusi dangkal), perempuan memiliki persentase lebih besar $(19,2 \%)$ dibandingkan dengan laki-laki $(15,4 \%)$. Pada skor 4 (saku gusi dalam) laki-laki memiliki persentase lebih besar $(15,4 \%)$ dibandingkan perempuan yang hanya $1,9 \%$.

\section{Analisa Bivariat}

Analisa bivariat pada penelitian ini bertujuan untuk mengetahui hubungan dua variabel yaitu antara variabel dependent dengan variabel independent. Pada penelitian ini analisa bivariat yang digunakan adalah uji Chi-Square. Variabel independent yang telah di kategorikan diuji apakah ada hubungan penggunaan tusuk gigi terhadap terjadinya saku gusi. Jika nilai $p<0,05 \mathrm{H}_{0}$ ditolak dan $\mathrm{H}_{\mathrm{a}}$ diterima.

Tabel 3. Hubungan Penggunaan Tusuk Gigi Terhadap Terjadinya Saku Gusi Pada Masyarakat Dusun II Desa marindal II Kecamatan Patumbak

\begin{tabular}{|c|c|c|c|c|c|c|c|c|}
\hline \multirow{2}{*}{ Total } & \multirow{2}{*}{$\mathrm{p}$-value } & \multirow{2}{*}{$\mathrm{df}$} & \multirow{2}{*}{$\left(x^{2}\right)$} & \multicolumn{4}{|c|}{ Skor CPITN } & \multirow{2}{*}{$\begin{array}{c}\text { Kelompok } \\
\text { Pengamatan }\end{array}$} \\
\hline & & & & 1 & 2 & 3 & 4 & \\
\hline 26 & & & & 0 & 3 & 14 & 9 & $\begin{array}{l}\text { Menggunakan } \\
\text { Tusuk Gigi }\end{array}$ \\
\hline & 0.0001 & 3 & 29.192 & & & & & \\
\hline 26 & & & & 3 & 19 & 4 & 0 & $\begin{array}{c}\text { Tidak Menggunakan } \\
\text { Tusuk Gigi }\end{array}$ \\
\hline 52 & & & & 3 & 22 & 18 & 9 & Total \\
\hline
\end{tabular}

Dari hasil uji chi-square di atas, maka dapat diketahui bahwa probabilitas adalah 0,0001. Oleh karena probabilitas $<0,05$, maka $\mathrm{H}_{0}$ ditolak atau bahwa menggunakan tusuk gigi dapat menyebabkan terjadinya saku gusi.

\section{Pembahasan}

Tusuk gigi merupakan benda yang sering dicari setelah mengonsumsi makanan berserat seperti sayur-sayuran dan daging (Doktersehat, 2015). Namun, sering kali pengguna asal mencongkel dari sela atau lubang gigi tempat sisa makanan tanpa memerhatikan anatomi gigi dan jaringan gusi di sekitarnya. Hal ini menyebabkan makanan yang terselip sulit dikeluarkan, bahkan semakin masuk ke jaringan gusi (Grace, 2011).

Berdasarkan hasil yang diperoleh dari 
52 responden yang menggunakan tusuk gigi dan tidak menggunakan tusuk gigi adalah skor status jaringan periodontal dengan skor 0 (sehat) tidak ada, skor 1 (pendarahan pada gusi) sebanyak 3 orang, skor 2 (kalkulus subgingiva) sebanyak 22 orang.

Skor 2 adalah skor tertinggi yang didapatkan berdasarkan penelitian terhadap responden. Hal ini mungkin disebabkan karena masyarakat desa masih memiliki kesadaran yang kurang untuk memelihara kebersihan dan kesehatan mulutnya sehingga memungkinkan bakteri untuk berkembang secara progresif menjadi plak atau kalkulus yang sangat besar.

Pada skor 3 yang menunjukkan adanya saku gusi dangkal sebanyak 18 orang. Rata-rata dari responden yang diteliti menggunakan tusuk gigi dengan frekuensi \pm 3 kali dalam sehari. Sedang pada skor 4 (saku gusi dalam), responden memiliki kebiasaan menggunakan tusuk gigi sudah lebih dari setahun dengan frekuensi 3 kali dalam sehari.

Disaat mengorek makanan di sela gigi, otomatis gusi ikut tertekan jika sering dilakukan dalam jangka waktu tertentu posisi gusi bisa turun. Hal ini dikarenakan gusi tidak dapat menahan tekanan tusuk gigi yang berukuran lebih besar. Kasus seperti ini biasanya sering terjadi pada gusi geraham belakang. Posisi gusi yang menurun menimbulkan rasa tidak nyaman. Gigi terasa seperti berlubang karena gusi yang biasa mengisi sela gigi bergeser beberapa milimeter (Moci, 2013).

Selain itu, kebiasaan menggunakan tusuk gigi dengan cara mencolok/menusuk dan mengungkit dapat mengganggu jaringan pendukung gigi dan dapat mengakibatkan terjadinya peradangan pada gusi (Erwana, 2013).

Dari hasil uji chi-square yang dilakukan pada responden yang menggunakan tusuk gigi dan tidak menggunakan tusuk gigi didapatkan hasil bahwa $p<0,05$ atau $0,0001<0,005$ sehingga hipotesis nol $\left(\mathrm{H}_{0}\right)$ ditolak yang berarti ada hubungan penggunaan tusuk gigi terhadap terjadinya saku gusi.

Sesuai dengan hasil penelitian di atas, Wahjuni (2012) mengatakan bahwa menggunakan tusuk gigi untuk membersihkan sela gigi dapat merusak gusi dan jaringan lunak di dalam mulut.

\section{KESIMPULAN}

1. Persentase skor tertinggi CPITN pada 26 responden yang menggunakan tusuk gigi dengan skor tertinggi adalah skor 3 sebanyak 14 orang $(53,8 \%)$. Skor 3 menunjukkan adanya saku gusi dangkal $(3,5-5,5 \mathrm{~mm})$.

2. Persentase skor tertinggi CPITN pada 26 responden yang tidak menggunakan tusuk gigi adalah skor 2 sebanyak 19 orang $(73,1 \%)$. Skor 2 menunjukkan adanya kalkulus subgingiva.

3. Persentase skor CPITN berdasarkan jenis kelamin adalah pada skor 0 laki-laki dan perempuan tidak ada yang memiliki gigi sehat. Pada skor 1, perempuan memiliki persentase lebih kecil (3,8\%) dibandingkan dengan laki-laki $(1,9 \%)$. Sementara untuk skor 2, laki-laki dan perempuan memiliki persentase yang sama yaitu 21,2\%. Pada skor 3 (saku gusi dangkal), perempuan memiliki persentase lebih besar $(19,2 \%)$ dibandingkan dengan laki-laki $(15,4 \%)$. Pada skor 4 (saku gusi dalam) laki-laki memiliki persentase lebih besar $(15,4 \%)$ dibandingkan perempuan yang hanya $1,9 \%$.

4. Hasil perhitungan dari uji chi-square bahwa hipotesis nol $\left(\mathrm{H}_{0}\right)$ ditolak yang berarti ada hubungan penggunaan tusuk gigi terhadap terjadinya saku gusi.

\section{SARAN}

1. Sebaiknya masyarakat memilih dental floss/benang gigi sebagai alat untuk membersihkan sisa makanan pada selasela gigi.

2. Hasil penelitian diharapkan dapat menambah wawasan dan pengetahuan tentang penggunaan tusuk gigi terhadap terjadinya saku gusi pada masyarakat 
Dusun II Desa Marindal II Kecamatan Patumbak.

3. Diharapkan hasil penelitian ini dapat menjadi bahan referensi bagi peneliti selanjutnya khususnya Jurusan Keperawatan Gigi Poltekkes Kemenkes Medan.

\section{DAFTAR PUSTAKA}

Arikunto, S. 2006. Prosedur Penelitian Suatu Pendekatan Praktek. Jakarta : Rineka Cipta.

Daliemunthe, S.H., 2002, Terapi periodontal. Medan: USU Press.

Dokter sehat. 2015. Sehatkah Menggunakan Tusuk Gigi http://doktersehat.com/sehatkahmenggunakan-tusuk-gigi/. (diakses tanggal 10 Maret 2016)

Erwana, A.F. 2013.Seputar Kesehatan Gigi dan Mulut. Yogyakarta : Rapha Publishing.

Fedi, P.F., Vernino, A.R., Gray, J.L. Silabus Periodonti. Alih bahasa: Amaliya Ed. 4. Jakarta:EGC Penerbit Buku Kedokteran.

Herijulianti, E., Indriani, T.S., Artini, S.2001. Pendidikan Kesehatan Gigi. Jakarta:EGC.

Manson, J.D., Eley, B.M.2012.Buku Ajar Periodonti. Alih bahasa: Anastasia.Ed.2 Jakarta: HIPOKRATES.

Moci, 2013.3 Bahaya Menggunakan Tusuk Gigi.

http://ciricara.com/2013/07/17/3-

bahaya-menggunakan-tusuk-gigi/.

(diakses tanggal 4 Maret 2016)

Mozartha, M. 2014.Apa Itu Saku Gusi. http://www.klikdokter.com/rubrikspe sialis/gigi-mulut/formula-kesehatangigi mulut/apa-itu-saku-gusi/. (diakses tanggal 15 Maret 2016)

Notoatmodjo, 2010. Metodologi Penelitian Kesehatan. Jakarta:Rineka Cipta.

Putri, M.H., Herijulianti, E., Nurjannah, N. 2010, Ilmu Pencegahan Penyakit Jaringan Keras dan Jaringan Pendukung Gigi. Jakarta:EGC Penerbit Buku Kedokteran.

Susanto,G.W. 2011. Terapi Gusi Untuk Kesehatan dan Kecantikan. Jakarta:Erlangga.

Wahjuni, F.R.2012.Kontroversi 101 Mitos Kesehatan. Jakarta : Penebar Plus.

Wikipedia. 2014. Tusuk Gigi http://id.m.wikipedia.org/wiki/Tusuk _gigi/. (diakses tanggal 5 Maret $\underline{2016)}$

Wikipedia. $2014 . \quad$ Gusi https://id.wikipedia.org/wiki/Gusi. (diakses tanggal 5 Maret 2016) 